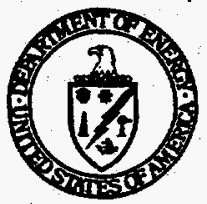

\title{
RCRA Corrective Action Corrective Measures Implementation
}

BACKGROUND:

STATUTE:

REGULATIONS: Proposed 40 CFR 264, SubpartS (65 FR 30798 tt seg-; July 27, 1990).

REFERENCE: DOE facilities. Briefs on RCRA Corrective Action.

RCRA Sections $3008(h), 3004(u), 3004(v)$
The 1984 passage of the Hazardous and Solid Waste Amendments (HSWA) to the Resource Conservation and Recovery Act (RCRA) etrengthened the U.S. Environmental Protection Agency'e (EPA's) ability to require hazardous waste management facility ownersloperators to perform corrective action to addreas roleases of hazardous waste or hazardous constituents. Undor RCRA Section 3008(h), EPA may leaus administrative orders compelling corrective action at interim stutus faclltios. Under RCRA Séction $3004(\mathrm{u})$, any permit issued to a treatment, storage, or disposal (TSD) facillty after November 8, 1984, must address corrective sction for releases of hazardous wasto or hazardous constituents from any solld wasto management unit (SWWU) at the faclity. Under RCRA Section 3004(V), EPA may compel a TSD facility ownorloperator to remediate releases that migrate beyond the facllity boundary.

On July 27, 1990 (56 FR 30798 gt seq.), EPA proposed a regulatory framework for implementing aspects of these stututory changes. This framework, proposed under 40 CFRSubparts, establishes requirements for conducting corrective action investigations and for evaluating, selecting, and implementing appropriate corrective action remedies at SWMUE. The proposed regulations define a SWMU broadly to include any discernible unitat which solid wastes were placed at any time, irrespective of whether the unitwas intended for the management of solid or hasardous wate. Some Sthtes and EPA Regions are currently using the proposed regulations as the basis for the performance of corrective action at permilted and interim status

The proposed corrective action framework involves four phases: RCRAFacility Aseosement (RFA), RCRA Facility Investigation (RF), Corrective Measures Study (CMS), and Corrective Measures implementation (CMill. This Information Brief provides en overylow of the CAll procese and ls one of a cerles of information

1. "RCRA Corrective Action Program Gulde - Interim Guldance," U.S. Department of Energy, Office of Environmontal Guidance, RCRNCERCLA Division, Guidance Manual, DOEJEH-0323, May 1993.

2. "RCRA Corrective Action Measures Study," U.S. Department of Energy, Ofiice of Environmental Guidance, RCRACERCLA Diviaion, Information Brief, EH-231-04710894 (August 1994).

\section{What is CMI and what are its objectfves?}

CMI is the process of designing constructing, operating maintaining, and monitoring the corrective remedy approved by the regulator on the basis of the information presented in the CMS (see Reference 2). The owner/operator is responsible for the performance of CMI while the regulator is responsible for CMI oversight.

The three objectives of CMI are: compliance with media cleanup standards (MCSs); completion of all source control measures; and the removal and/or decontamination of all equipment, devices, or structures used in conducting the corrective measure. MCS compliance must be achieved at all compliance points specified in the facility permit (or administrative order) [proposed 40 CFR 264.525(e)]. The owner/operator must demonstrate that these objectives have been achieved to be released from the corrective action schedule of compliance specified in the facility permit (or corrective administrative order) [proposed 40 CFR 264.530].
What types of planning requirements are associated with CMI?

A regulator may require a facility owner/operator to prepare detailed construction plans and specifications to implement the approved remedy at a facility. Such plans and specifications are subject to review and approval or modification by the regulator and must be developed and submitted in accordance with the schedule of compliance specified in the facility's permit (or corrective action order). CMI plans and specifications must include at least the following items: designs and specifications for units in which hazardous wastes and nonhazardous wastes will be managed, as specified in the approved remedy; implementation and long-term maintenance plans; project schedule; and construction quality assurance program [proposed 40 CFR 264.527.(a)].

Planning the implementation of the corrective measure may aiso involve the development of program management, operation and 
maintenance, data collection quality assurance, health and safety, and a variety of other types of plans (see Reference 1, Chapter 6, Module 6-1). Once the plans and specifications for the remedy are approved by the regulator, the owner/operator must implement the remedy in accordance with these plans and specifications and in a manner that is consistent with the objectives specified for the remedy during the remedy selection process [proposed 40 CFR 264.527(b)]. Reference 2 lists the criteria for remedies that must be considered by regulators in evaluating alternative corrective measures.

\section{What CMI requirements must be specified in the facility permit?}

When modifying a facility permit to describe the remedy selected, the regulator must also specify: the technical features of the remedy necessary to achieve the standards for remedies; MCSs; the point of compliance for achieving MCSs; requirements applicableto standards for the management of wastes; requirements for removal, decontamination, closure, or post-closure of units, equipment, devices, or structures that will be used to implement the remedy; requirements for initiating and completing the major technical features and milestones of the remedy; and requirements for submission of reports and other information [proposed 40 CFR 264.526(b)].

\section{How is the progress of CMI monitored?}

The regulator monitors the progress of CMI through periodic review of progress reports and on-site inspections. The regulator may require the owner/operator to provide progress reports during the design, construction, operation, and maintenance of the remedy. Such reports include: asummary of the progress of remedy implementation including results of monitoring and sampling activities, progress in meetingmedia cleanup standards, and description of other remediation activities; problems encountered during the reporting period and actions taken or proposed to resolve the problems; changes in personnel conducting or managing the remedial effort; project work for the next reporting period; and copies of laboratory and field sampling reports.

In addition, the regulator may specify the frequency and format of CMI progress reports [proposed 40 CFR 264.528].

Review of remediation activities will also include on-site inspections and oversight of remedy design, construction, operation and maintenance to ensure that remediès are effectively implemented. Onsite inspections will focus on areas identified for oversight in progress reports or prior reviews [55 FR 30837; July 27, 1990]. Based on periodic review of the progress of the remedy, the regulator may modify the permit schedule of compliance to require additional remedial measures to ensure prompt completion, safety, effectiveness, protectiveness, or reliability of the remedy [proposed 40 CFR 264.529].

\section{What if the remedy fails to perform as expected?}

Based on performance information' developed by the owner/ operator (or other relevant information), the regulator may determine that compliance with a requirement for a remedy is not technically practicable. In making this determination, the regulator is required to consider the efforts to achieve compliance and the ability of other currently available or new and innovative methods or technologies to practicably achieve compliance [proposed 40 CFR 264.531(a)].
Once a determination of technical impracticability is made, the regulator must modify the facility permit schedule of compliance to specify: further measures that may be necessary to control exposure of humans or the environment to residual contamination; and altemate levels or measures for cleaning up contaminated media, controlling the sources of contamination, or removing or decontaminating equipment, units, devices, or structures, which are technically practicable and are consistent with the overall objectives of the remedy [proposed 40 CFR 264.531(b)]. For example, if treatment of contaminated soils to specified levels is not technically feasible, the soils may need to be covered or disposed of in a unit with upgraded engineering controls for release prevention [55 FR 30838; July 27, 1990].

A determination of technical impracticability, however, does not relieve the owner/operator of his ultimate responsibility to achieve the specific remedy requirement. If subsequent changes in remedial technology or changes in site conditions make achievement of the requirement technically practicable, the regulator retains the authority to modify the permit (if the permit is still in force) or to take other appropriate action to require attainment of the standard or other requirement [55 FR 30838; July 27, 1990].

\section{When does corrective action end?}

When a remedy has been completed, owners/operators must submit a request for termination of the corrective action schedule of compliance according to the procedures for Class III permit modifications in 40 CFR 270.42. The request must include a certification stating that: compliance with all MCSs (or altemate levels) has been achieved as specified in the permit; all actions required to control the source(s) or contamination have been satisfied; and procedures speoified for removal, decontamination, closure, or post-closure care of units, equipment, devices, or structires required to complete the remedy have been complied with [proposed 40 CFR 264.530(a)].

The certification must be signed by the owner/operator and independent professionals skilled in the appropriate technical disciplines [proposed 40 CFR $264.530($ b)]. If the owner/operator completes a corrective measure at a unit widely separated from and affecting different media than other units at the facility, the owner/ operator may requestapartial release from the $R C R A$ correctiveaction program (55 FR 30838; July 27, 1990).

Upon receipt of the request and certification, the regulator determines whether the remedy has been completed in accordance with permit requirements. If the regulator determines that corrective action is complete, the permit is modified to terminate the corrective action schedule of compliance [proposed 40 CFR 264.530(c)].

Questions of policy or questions requiring policy decisions will not be dealt with in EH-231 Information Briefs unless that policy has already been established through appropriate documentation. Please refer any questions concerning the subjectmaterial covered in this Information Brief to Jerry Coalgate, RCRACERCLA Division, EH-231, (202)586-6075.

(

